\title{
Cytotoxic activity of Pinus cembra L. needle extract: A preliminary study on HeLa cell line
}

\author{
Cristina LUNGU ${ }^{1}$, Cosmin-Teodor MIHAI ${ }^{2,3}$, Gabriela VOCHITA³, Daniela GHERGHEL ${ }^{3}$, \\ Sorin-Dan MIRON ${ }^{1}$, Ana Clara APROTOSOAIE ${ }^{1}$, Anca MIRON ${ }^{1}$ \\ 1"Grigore T. Popa" University of Medicine and Pharmacy, Iasi, Romania \\ ${ }^{2}$ Advanced Centre for Research and Development in Experimental Medicine (CEMEX), "Grigore T. Popa" University \\ of Medicine and Pharmacy, lasi, Romania \\ ${ }^{3}$ Institute of Biological Research/National Institute of Research and Development for Biological Sciences, Iasi,
}

Romania

\begin{abstract}
The aim of this study was to investigate the cytotoxic effects of a hydromethanolic extract obtained from cembran pine needles in HeLa cell line. In this respect, the effects of needle extract on protein synthesis, viability, proliferation and cell cycle in HeLa cells were evaluated after $48 \mathrm{~h}$ treatment. Cembran pine needle extract dose-dependently decreased protein synthesis in HeLa cells causing $44.26 \%$ reduction in protein synthesis at $100 \mu \mathrm{g} / \mathrm{ml}$. At 25, 50 and $100 \mu \mathrm{g} / \mathrm{ml}$, it increased cell death in comparison with the control $(20.99 \%, 21.49 \%$ and $23.63 \%$, respectively vs. $9.83 \%)$. In addition, at $100 \mu \mathrm{g} /$ $\mathrm{ml}$, cembran pine needle extract showed a remarkable antiproliferative effect whereas at 25 and $50 \mu \mathrm{g} / \mathrm{ml}$, it induced sub-G1 phase cells accumulation (11.68 $\pm 0.81 \%$ and $14.69 \pm 0.56 \%$, respectively in comparison with control, $6.03 \pm$ $0.55 \%$ ), an indicator of proapoptotic effects. Taken together, these results indicate that cembran pine needles are a source of compounds with antitumor potential which needs to be further investigated and exploited.
\end{abstract}

Keywords: cembran pine needles, HeLa cell line, cytotoxicity, viability, proliferation, proapoptotic effect

\section{INTRODUCTION}

The genus Pinus includes more than 100 species spread worldwide, mainly in the northern hemisphere but also in the tropical and subtropical areas [1]. The therapeutic benefits of pine species are known for more than 2000 years. Hippocrates mentioned pine bark as a remedy for inflammatory disorders whereas in the Middle Ages pine bark was predominantly used for wound healing. Pine inner bark (fresh, dried, roasted) was eaten by the natives in northern Europe and America due to its high contents in flavonoids and vitamin C [2]. Pine needles have also been used in the traditional medicine for the treatment of various ailments (cardiovascular and respiratory diseases, diabetes mellitus) [3]. Nowadays research has shown numerous biological effects for pine needle extracts (many of them supporting the traditional medicinal uses) and has also unveiled novel ones such as antitumor potential. Pine needle extracts were reported to exhibit cytotoxic effects against a wide 
range of cancer cells. In addition, numerous compounds with promising antitumor activity have been isolated from pine needles [4-6].

A methanol extract of Pinus sylvestris L. (Scots pine) needles reduced the viability of different human cancer cells lines with IC50 values ranging from 86.37 to $35.56 \mu \mathrm{g} / \mathrm{ml}$ after $48 \mathrm{~h}$ treatment. The extract showed the highest cytotoxicity against estrogen receptor negative breast cancer cells MDA-MB-231 and had good cytotoxic effects (IC50 $=52-57 \mu \mathrm{g} / \mathrm{ml}$ ) against promyelocytic leukemia $\mathrm{HL}-60$, colon adenocarcinoma SW480, lung adenocarcinoma LU-1 and liver hepatocellular carcinoma HepG2 cells [4].

The hexane layer of a methanol extract of Pinus densiflora Sieb. \& Zucc. needles showed remarkable antiproliferative effects in different gastric cancer cell lines (AGS, YCC-2, MKN28, SNU-216, SNU-601 and SNU-66) with IC50 values of $35.31-45.69 \mu \mathrm{g} / \mathrm{ml}$. G1/S cell cycle arrest and induction of premature cell senescence were found to be the main mechanisms underlying the antiproliferative activity in gastric cancer cells [5].

Secondary metabolites isolated from pine needles were also reported to be cytotoxic against cancer cell lines. Chrysin and, to a lesser extent, pinocembrin and tiliroside, flavonoids isolated from the water extract of Pinus morrisonicola (Hayata) needles, induced apoptosis and suppressed migration and invasion in human glioblastoma GBM8901 cells. Moreover, chrysin sensitized glioblastoma cells resistant to temozolomide via downregulation of autophagy and expression of O6-methylguanine-DNA-

methyltransferase, enzyme playing a key role in chemoresistance. Same effects were detected for the needle water extract [6]. At $30 \mu \mathrm{g} / \mathrm{ml}, 15$-ethyl-18methyl pinifolate, a diterpene isolated from Scots pine needles, reduced the proliferation rate of human cervical carcinoma HeLa, neuroblastoma SK-N-SH and hepatocellular carcinoma BEL-7402 cells by $88.18 \%$, $89.11 \%$ and $65.88 \%$, respectively [7].

In search for novel sources of antitumor compounds, our research focused on cembran pine (Pinus cembra L.). Cembran pine grows at high altitude sites in the Carpathian Mountains but also in the Central European Alps, sites characterized by low temperatures, high levels of ozone and irradiance [8]. Our previous investigations found significant levels of polyphenols, antioxidant and antimicrobial activities in the bark hydromethanolic extract [9]. The needle hydromethanolic extract and essential oil and the twig essential oil showed moderate antioxidant and antimicrobial effects $[9,10]$.

The present study describes a preliminary screening of the cytotoxic potential of the cembran pine needle hydromethanolic extract on HeLa cells (human cervical cancer cell line). In this respect, protein synthesis, viability, proliferation and cell cycle were investigated in HeLa cells after $48 \mathrm{~h}$ exposure to needle hydromethanolic extract. To the best of our knowledge, this is the first report on the evaluation of the cytotoxic potential of cembran pine needles uniformity [1]. Another paper reports the development and validation of a NIR spectroscopic method based on multivariate calibration for simultaneous determination of four drugs, i.e. rifampicin, isoniazid, pyrazinamide and ethambutol, allowing the quality control of fixed-dose combination tablets employed in tuberculosis treatment [2]. Some works dealing with the chemical characterization of tablets by NIR spectroscopy report the simultaneous assay of active ingredient and excipients $[3,4,5]$. Besides chemical characterization, some papers report the simultaneous determination of physical and pharmaceutical properties of tablets by NIR, such as hardness, disintegration time and drug dissolution [6, $7,8,9,10]$.

\section{MATERIALS AND METHODS}

\section{Materials}

All reagents and solvents were of analytical grade. HeLa cells were purchased from the American Type Culture Collection (ATCC; Manassas, VA, USA).

\section{Plant material and extraction}

The source and extraction procedure of cembran pine needles have been previously reported [9].

\section{Cellular protein assay}

The effect of cembran pine needle extract on protein synthesis in HeLa cells was estimated spectrophotometrically using methylene blue according to the method described by Kreja et al. [11].

\section{Cell viability assay}

A flow cytometry-based assay was used to assess the effects of cembran pine needle extract on HeLa cells 


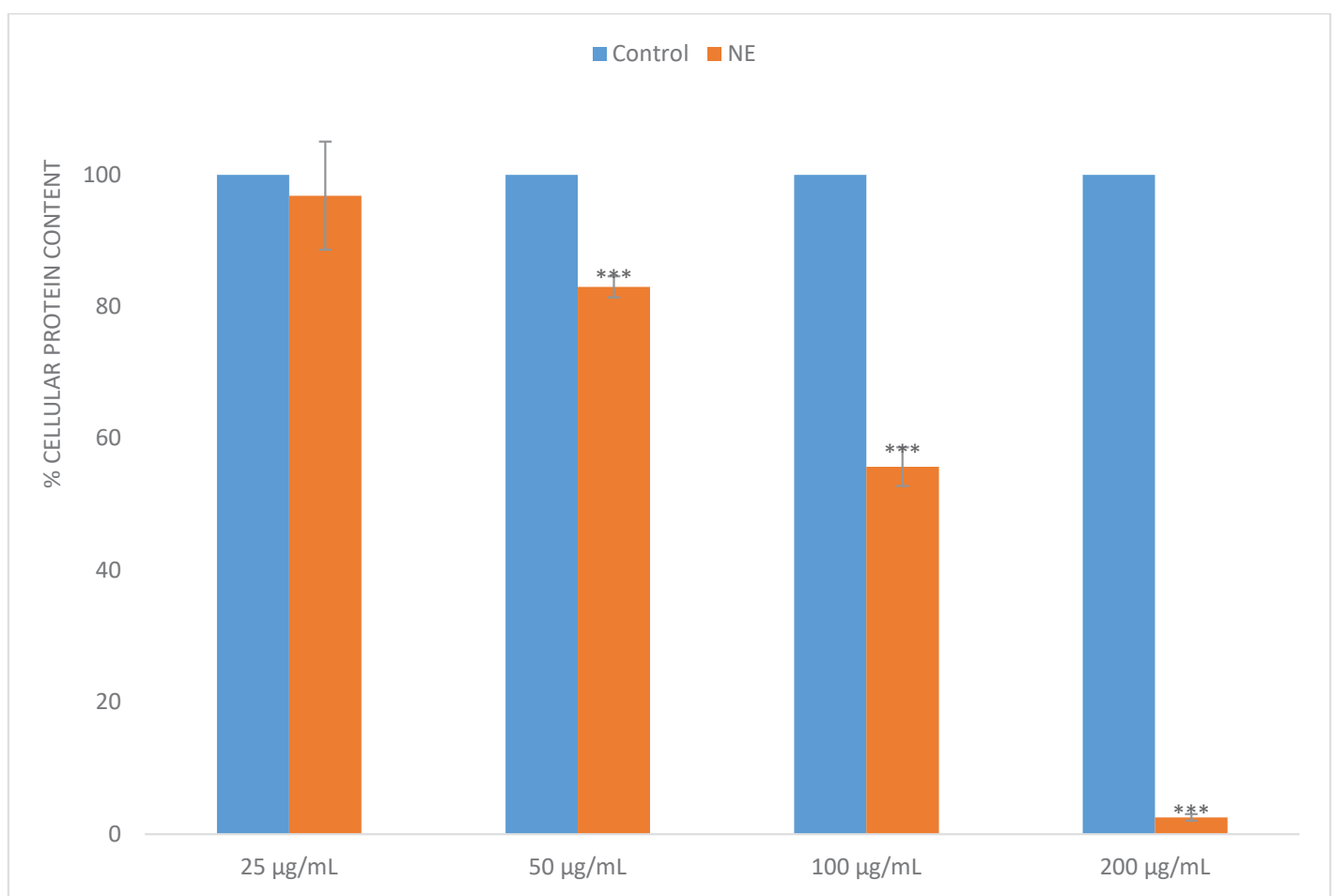

FIGURE 1. The effect of cembran pine needle extract (NE) on cellular protein content in HeLa cells after $48 \mathrm{~h}$ treatment $(* * * p<0.001)$

viability. 7-Aminoactinomycin D (7-AAD), a fluorescent DNA binding agent, allowed to discriminate between dead and viable HeLa cells $[12,13]$.

\section{Cell proliferation assay}

The influence of cembran pine needle extract on HeLa cells proliferation was investigated by flow cytometry using the fluorescent staining dye carboxyfluorescein succinimidyl ester (CFSE) [14].

\section{Cell cycle assay}

Cell cycle analysis was performed by nuclear isolation media-4',6-diamidino-2-phenylindole dihydrochloride (NIM-DAPI) staining followed by flow cytometry quantification for percentages of HeLa cells in G0/G1, S, G2/M and sub-G1 phases [15].

\section{Statistical analysis}

All experiments were performed in triplicate and the results were expressed as mean \pm standard error. Statistical analysis was performed using Student's $t$ test; $p<0.05$ was considered statistically significant.

\section{RESULTS AND DISCUSSION}

\section{Cellular protein assay}

A methylene blue assay was used for the initial screening of the cytotoxic activity of cembran pine needle extract. The latter induced a concentrationdependent reduction in the protein content of HeLa cells after $48 \mathrm{~h}$ treatment. At $100 \mu \mathrm{g} / \mathrm{ml}$, the extract lowered the cellular protein content up to $55.74 \pm$ $2.93 \%$ whereas at $200 \mu \mathrm{g} / \mathrm{ml}$ it almost completely abolished the protein synthesis in HeLa cells (Figure 1).

\section{Cell viability assay}

The percentages of dead and viable HeLa cells after 48 $\mathrm{h}$ treatment with cembran pine needle extract were determined by flow cytometry after staining with 7-AAD. The latter penetrates only dead or damaged cells, being excluded by the intact ones. So, dead cells can be easily discriminated from viable cells due to their fluorescent signal $[12,13]$. As shown in Figure 2, cembran pine needle extract reduced the viability of HeLa cells in a dose-dependent manner. The percentage of dead HeLa cells increased from $20.99 \pm$ $0.07 \%$ to $81.31 \pm 2.41 \%$ after $48 \mathrm{~h}$ exposure to needle 


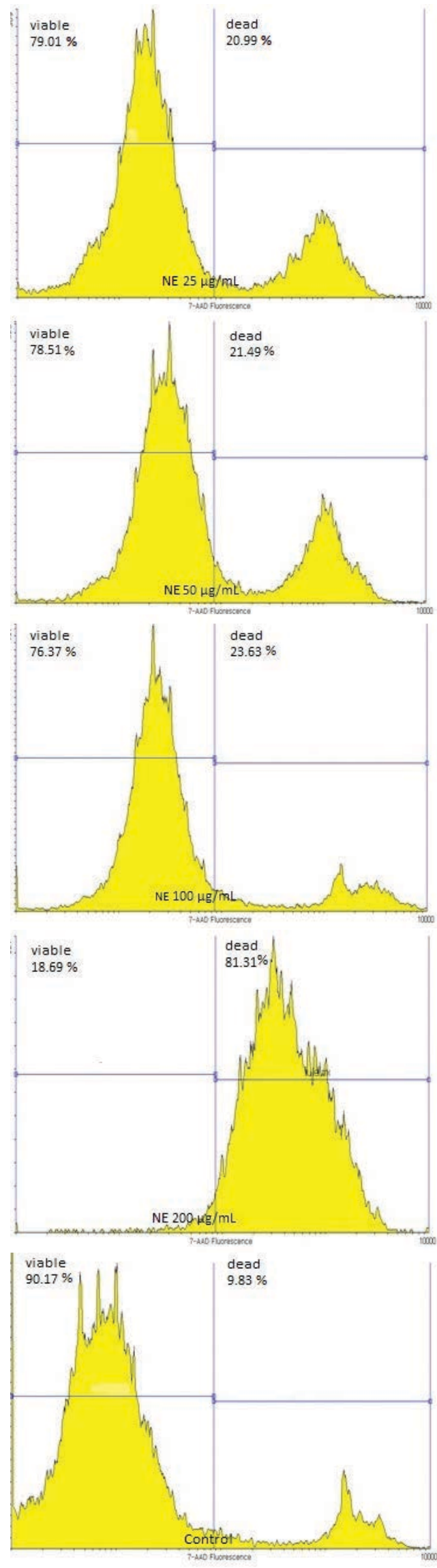

FIGURE 2. The effect of cembran pine needle extract (NE) on HeLa cells viability after $48 h$ treatment extract at 25 and $200 \mu \mathrm{g} / \mathrm{ml}$, respectively. As needle extract was highly cytotoxic at $200 \mu \mathrm{g} / \mathrm{ml}$, this dose was excluded in further assays.

\section{Cell proliferation assay}

CFSE, a fluorochrome which covalently binds to intracellular molecules, was used to evaluate the proliferation dynamics in HeLa cells exposed to cembran pine needle extract. In cell division, CFSE is equally distributed between the two daughter cells which therefore will be less fluorescent. An increase in the fluorescence intensity indicates a blockage of cell division [14]. The effects on cell proliferation were evaluated after 24,48 and $72 \mathrm{~h}$ of culture of CFSE labeled HeLa cells, untreated (control) and treated with cembran pine needle extract for $48 \mathrm{~h}$. As shown in Figures 3 and 4, the extract showed a remarkable antiproliferative effect at $100 \mu \mathrm{g} / \mathrm{ml}$ indicated by a higher value of the mean fluorescence intensity (\% X) in the treated HeLa cells in comparison with the control ( $56.56 \pm 1.67 \%$ vs. $28.95 \pm 1.27 \%)$.
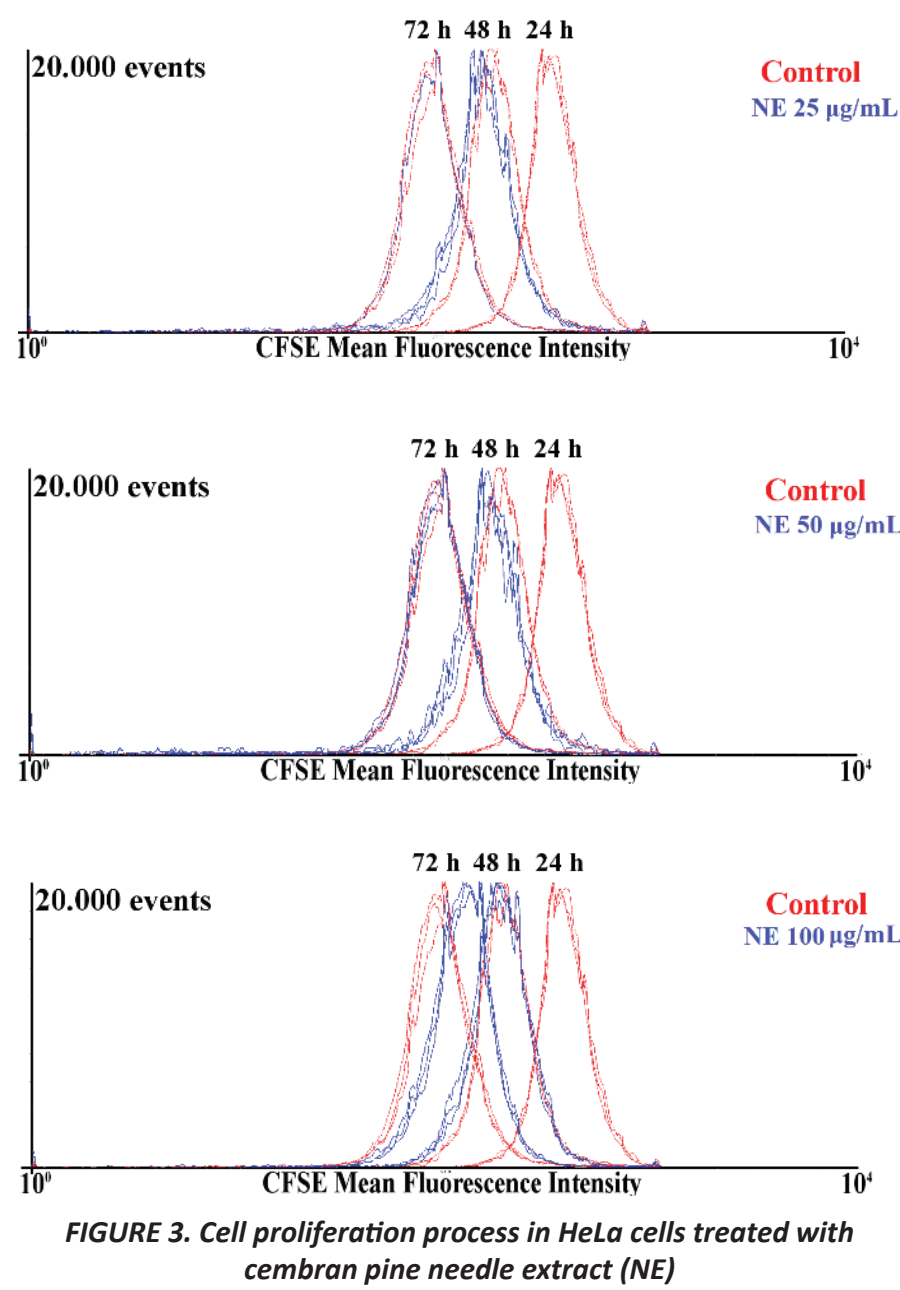


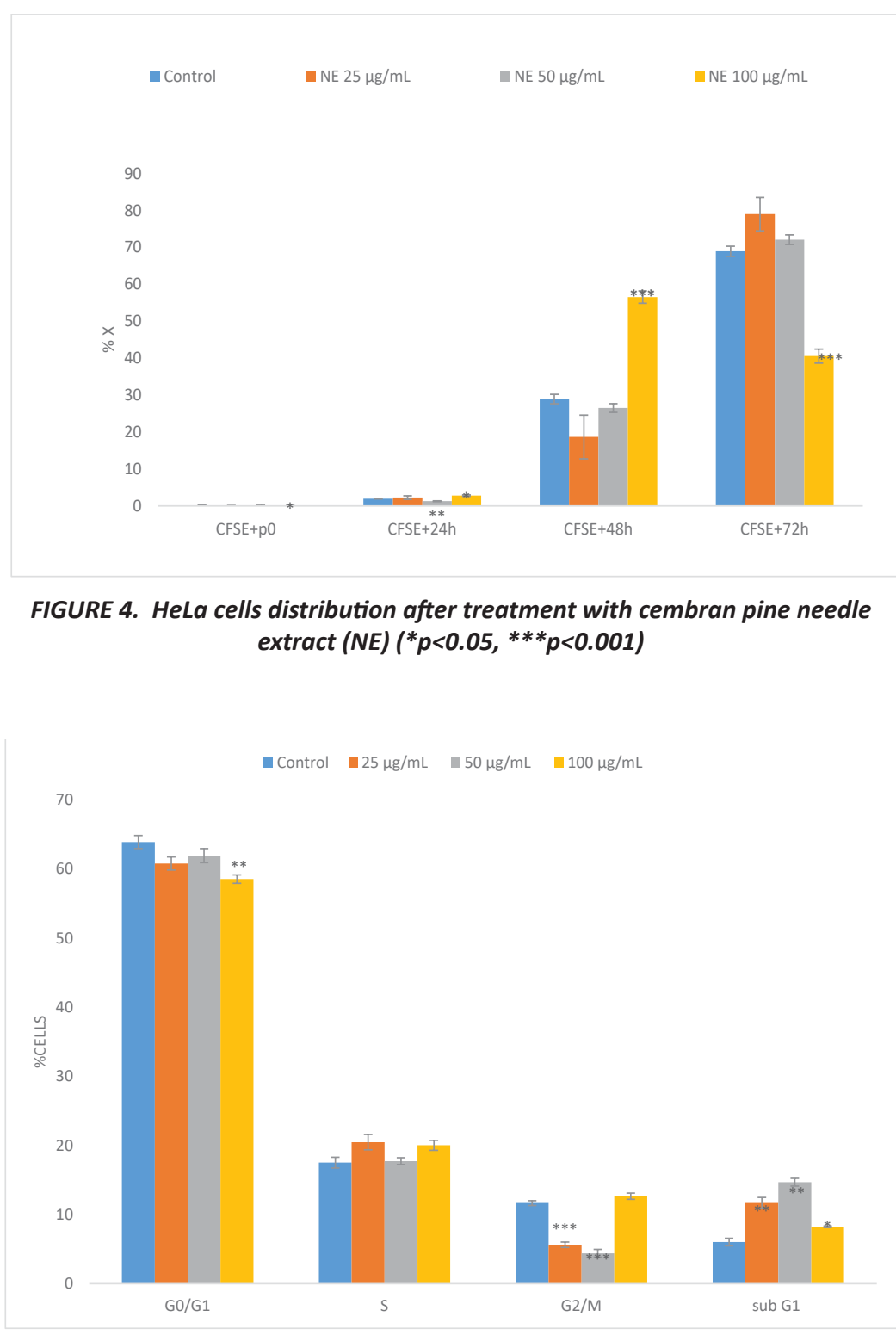

FIGURE 6. Percentages of HeLa cells in different cell cycle phases after $48 \mathrm{~h}$ treatment with cembran pine needle extract $\left({ }^{*} p<0.05,{ }^{*} p<0.01, * * * p<0.001\right)$

\section{Cell cycle assay}

Percentages of HeLa cells in different cell cycle phases after $48 \mathrm{~h}$ treatment with cembran pine needle extract were quantified by flow cytometry using NIM-DAPI, a DNA-binding fluorochrome [15]. The cell cycle measurements showed significant accumulation of HeLa cells in the sub-G1 phase after $48 \mathrm{~h}$ exposure to 25 and $50 \mu \mathrm{g} / \mathrm{ml}$ of cembran pine needle extract in comparison with the control $(11.68 \pm 0.81 \%$ and 14.69 $\pm 0.56 \%$, respectively vs. $6.03 \pm 0.55 \%$ ) (Figures 5 and 6). As apoptotic cells accumulate in the sub-G1 phase, it is obvious that cembran pine needle extract is endowed with proapoptotic effects.
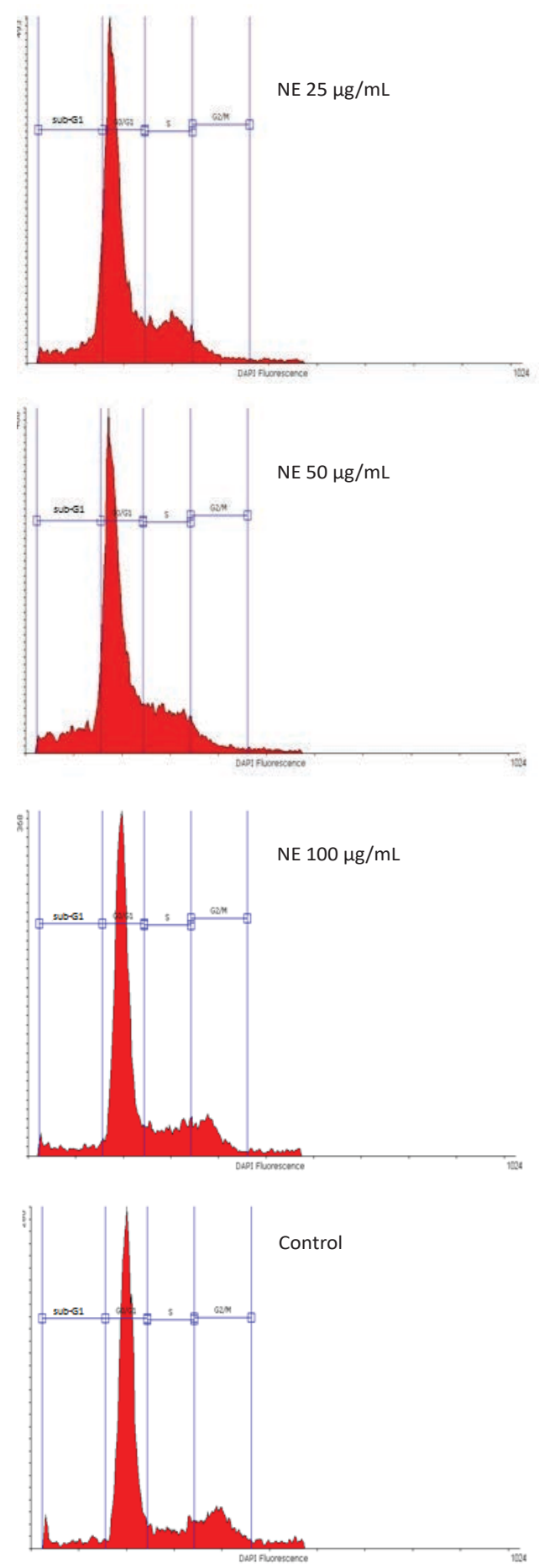

FIGURE 5. Cell cycle progression in HeLa cells treated with cembran pine needle extract (NE)

\section{CONCLUSIONS}

The experimental data indicate that cembran pine needle extract effectively reduces the protein synthesis, viability and proliferation and induces apoptosis in HeLa cells. Further research is required to isolate the compounds responsible for the antitumor effects. 


\section{REFERENCES}

1. Koutsaviti A, Toutoungy S, Saliba R, Loupassaki S, Tzakou O, Roussis $V$, loannou E. Antioxidant potential of pine needles: a systematic study on the essential oils and extracts of 46 species of the genus Pinus. Foods. 2021;10(1):142.

2. Packer L, Rimbach $G$, Virgili F. Antioxidant activity and biologic properties of a procyanidin-rich extract from pine (Pinus maritima bark), Pycnogenol. Free Radic Biol Med. 1999;27(5-6):704-724.

3. Lin SC, Chang CM, Deng TS. Enzymatic hot pressurized fluids extraction of polyphenolics from Pinus taiwanensis and Pinus morrisonicola. J Taiwan Inst Chem Eng. 2009;40:136-142.

4. Hoai NT, Duc HV, Thao do T, Orav A, Raal A. Selectivity of Pinus sylvestris extract and essential oil to estrogen-insensitive breast cancer cells Pinus sylvestris against cancer cells. Pharmacogn Mag. 2015;11(Suppl2):S290-S295.

5. Kim W, Park C, Park J, Cheong H, Kim SJ. Pine needle hexane extract promote cell cycle arrest and premature senescence via p27KIP1 up-regulation gastric cancer cells. Food Sci Biotechnol. 2020;29(6):845-853.

6. Liao CL, Chen CM, Chang YZ, Liu GY, Hung HC, Hsieh TY, Lin CL. Pine (Pinus morrisonicola Hayata) needle extracts sensitize GBM8901 glioblastoma cells to temozolomide by downregulating autophagy and 06-methylguanine-DNA-methyltransferase expression. J Agric Food Chem. 2014;62(43):10458-10467.

7. Wang Q, Rong Z, Teng J, Takaishi Y, Duan HQ. Two new antitumor diterpenes from Pinus sylvestris. Chin Chem Lett. 2008;19:187-189.

8. Wieser G, Manning WJ, Tausz M, Bytnerowicz A. Evidence for potential impacts of ozone on Pinus cembra L. at mountain sites in Europe. An overview. Environ Pollut. 2006;139:53-58.
9. Lungu Apetrei C, Tuchilus C, Aprotosoaie AC, Oprea A, Malterud KE, Miron A. Chemical, antioxidant and antimicrobial investigations of Pinus cembra L. bark and needles. Molecules. 2011;16:7773-7788.

10. Lungu Apetrei C, Spac A, Brebu M, Tuchilus C, Miron A. Composition, and antioxidant and antimicrobial activities of the essential oils of a full-grown Pinus cembra L. tree from the Calimani Mountains (Romania). J Serb Chem Soc. 2013;78(1):27-37.

11. Kreja L, Seidel HJ. On the cytotoxicity of some microbial volatile organic compounds as studied in the human lung cell line A549. Chemosphere. 2002;49:105-110.

12. Nechita A, Cotea V, Nechita CB. Study of cytostatic and cytotoxic activity of several polyphenolic extracts obtained from Vitis vinifera. Not Bot Horti Agrobo. 2012;40(1):216-221.

13. Mihailescu Amalinei RL, Trifan A, Cioanca O, Miron SD, Mihai CT, Rotinberg P, Miron A. Polyphenol-rich extract from Pinus sylvestris L. bark - chemical and antitumor studies. Rev Med Chir Soc Med Nat lasi. 2014;118(2):551-557.

14. Duan XM, Huang J, Ma HX, Wang XQ, Che YY, Tan Y, Wang YP. A flow cytometric assay for simultaneously measuring the proliferation and cytotoxicity of cytokine induced killer cells in combination with carboxyfluorescein succinimidyl ester (CFSE) labeling. Afr J Biotechnol. 2011;10(65):14598-14607.

15. Bortolotti C, Kunit T, Mode A et al. The phytostilbene resveratrol induces apoptosis in INS-1E rat insulinoma cells. Cell Physiol Biochem. 2009;23:245-254. 